\title{
Novel hydroxycinnamamide from morpholine and pyrrolidine: Synthesis, characterization, docking study, and anticancer activity against P388 leukemia murine cells
}

\author{
Firdaus $^{1 *}$, Nunuk Hariani Soekamto ${ }^{1}$, Syadza Firdausiah ${ }^{1}$, Herlina Rasyid $^{1,2}$, Nur Asmi $^{1}$, Muzdalifah Waelulu ${ }^{1}$ \\ ${ }^{1}$ Hasanuddin University, Makassar, Indonesia. \\ ${ }^{2}$ Austrian-Indonesian Center for Computational Chemistry, Chemistry Department, Gadjah Mada University, Yogyakarta, Indonesia.
}

\begin{tabular}{l}
\hline ARTICLE INFO \\
\hline Received on: 04/05/2020 \\
Accepted on: 25/09/2020 \\
Available online: 05/01/2021 \\
\\
\hline Key words: \\
Amidation, caffeic acid, \\
cytotoxic, molecular docking, \\
p-coumaric acid.
\end{tabular}

\begin{abstract}
This study aimed to synthesize $N$-(p-coumaroyl)morpholine (6a), $N$-caffeoylmorpholine $(\mathbf{6 b}), N$-(p-coumaroyl) pyrrolidine (7a), and $N$-caffeoylpyrrolidine (7b) from p-coumaric and caffeic acid through acetylation, chlorination, amidation, and deacetylation reactions. The characterization of these compounds was committed by Fourier transform infra-red and NMR spectroscopy, while the anticancer activity was studied against murine leukemia P388 cells. Compounds $\mathbf{6 a}, \mathbf{6 b}$, and $\mathbf{7 b}$ were found to have remarkable anticancer activity with $\mathrm{IC}_{50}$ values $\leq 50 \mu \mathrm{g} / \mathrm{ml}$. Furthermore, $\mathbf{6 b}$ performed very active anticancer activity with $\mathrm{IC}_{50}$ of $1.48 \mu \mathrm{g} / \mathrm{ml}$. The molecular docking study of compound $\mathbf{6 b}$ against the Top1 protein receptor showed the presence of hydrogen bond interactions on Asn722 and Thr718 amino acid residue. Thus, these compounds are promising candidates as anticancer agents.
\end{abstract}

\section{INTRODUCTION}

Cancer is still a significant health problem worldwide (Magalhaes et al., 2018; Siegel et al., 2019), which is the second leading cause of death after heart disease (Sudhakar, 2009). During 2018, there were 9.6 million deaths caused by cancer (Bray et al., 2018). The cancer cells are characterized by uncontrolled cellular growth, damage of tissue, and ability to spread to other organs that are not directly connected with them (Dutta et al., 2013; Sarkar et al., 2013). The majority of deaths by cancer were caused by metastases (Dillekås et al., 2019).

Several approaches could be applied as cancer treatment; however, one of the most important treatments is chemotherapy (Chorawala et al., 2012). Chemotherapy is a treatment that uses chemicals to suppress the growth of cancer cells (Kakde et al., 2011). However, these chemicals can cause serious adverse side effects on the patient's body because they do not only attack the

\section{${ }^{*}$ Corresponding Author}

Firdaus, Hasanuddin University, Makassar, Indonesia.

E-mail: firdaus@unhas.ac.id cancer cells but also attack the healthy cells (Chorawala et al., 2012; Yao et al., 2014). Therefore, many researchers are still paying attention to the discovery of new drugs (Said et al., 2013).

Hydroxycinnamic compounds exhibited antioxidant activity, so it is supposed to be able to prevent diseases that accompany oxidative stress such as cancer, cardiovascular disease, and other chronic diseases (Rocha et al., 2012; Spencer et al., 2008). The compounds included in this group are $p$-coumaric acid, ferulic acid, caffeic acid, and cinnamic acid (Georgiev et al., 2012; Teixeira et al., 2013). There are many kinds of reported evidence about the truth of the allegation that have been reported. Caffeic acid phenethyl ester (CAPE) is an antioxidant and is believed to have potential use in the treatment of patients with advanced oral cancer (Kuo et al., 2015; Ozturk et al., 2012). CAPE also has the activity as 5-lipoxygenase (5-LO) inhibitors. 5-LO is a catalyst for the transformation of arachidonic acid into leukotrienes, which have been directly implicated in inflammatory diseases like asthma, atherosclerosis, and rheumatoid arthritis (Boudreau et al., 2012). Some amides derived from cinnamic acid showed antioxidant activity and also could act as inhibitors of acetylcholinesterase and butyrylcholinesterase; hence, they are potentially used for the prevention or treatment of Alzheimer's disease. 
Some amide derivatives from cinnamic acid have been synthesized, and their antioxidant, anti-inflammatory, and anticancer activities have also been evaluated, such as 4-O-(2"-O-acetyl-6"-O$p$-coumaroyl- $\beta$ - $D$-glucopyranosyl)- $p$-coumaric acid, which possess a potential use in the treatment of lung cancer (Peng et al., 2015), amides of caffeic acid which possessed moderate to good anti-inflammatory activities (Liu et al., 2014), and thiourea of p-methoxycinnamamide which showed activity as a chemopreventive agent on fibrosarcoma in mice (Ekowati et al., 2012).

Some studies proved that hydroxycinnamoyl and cyclic amines moieties play a role in antioxidant and anticancer activities of the compounds (Firdaus et al., 2017; Rajan et al., 2001). In designing the target of active compounds, in this study, two groups have been considered. For the first target compound, we combined hydroxycinnamoil moiety with morpholine because the compounds containing the morpholine group, which showed a multidrug resistance (MDR) effect on MDR cancer cells (Yao et al., 2014). For the second target compound, hydroxycinnamoil moiety was combined with a heterocyclic amine, pyrrolidine. Other chemical constituents bearing morpholine and pyrrolidine moieties, such as tetrazole (Lukowska-Chojnacka et al., 2019), pyridazinone (Kamble et al., 2017), pyrazolidine (Surendra Kumar et al., 2017), and kojic acid derivatives (Karakaya et al., 2019), have been obtained and have showed moderate-to-high biological activities, such as antifungal, antioxidant, antimicrobial, cytotoxic, and tyrosinase inhibitory activities.

Several methods have been applied to synthesize the analogous of $p$-coumaramide and caffeamide. Here, we report four new $p$-coumaramide and caffeamide compounds from morpholine and pyrrolidine, and also evaluated their in vitro cytotoxic activity against P388 leukemia cells. Furthermore, a molecular docking study was conducted to investigate the interaction of the active compound against the protein receptor, which plays a role in the inhibition of cancer cell growth (Lu et al., 2013; Qin et al., 2016). Compound $\mathbf{6 b}$ performed vigorous anticancer activity with an $\mathrm{IC}_{50}$ value $<10 \mu \mathrm{g} / \mathrm{ml}$. It also showed a lower docking score than the other compounds and had an intermolecular interaction against the amino acid residue of the protein receptor.

\section{MATERIALS AND METHODS}

Melting points were measured using the thermal melting point apparatus, the Fourier transform infra-red (FTIR) spectra were recorded from Shimadzu IR-Prestige-21 spectrophotometer, and the nuclear magnetic resonance (NMR) spectra were obtained from Agilent $500 \mathrm{MHz}$ spectrometer.

\section{Materials}

Except $p$-coumaric and caffeic acid that were purchased from Sigma Aldrich, all materials used in this research were purchased from Merck.

\section{Synthesis and characterization}

These reactions were performed according to the previously reported method (Firdaus et al., 2017).

\section{Synthesis of Acetic Anhydride $2 a$ and $2 b$}

In this reaction step, both compounds were obtained as yellow solids which were recrystallized by using methanol for $\mathbf{2 a}$ to obtain a pale yellow crystalline and ethyl acetate and n-hexane for $\mathbf{2} \mathbf{b}$ to obtain a white crystalline.

Compound 2a. m.p. of $205^{\circ} \mathrm{C}-207^{\circ} \mathrm{C}$. IR $(\mathrm{KBr}) v, \mathrm{~cm}^{-1}$ : 1,747.51 ( $\mathrm{C}=\mathrm{O}$ acetyl), 1,681.93 $(\mathrm{C}=\mathrm{O}$ conjugated $), 2,819.93 \&$ 2,981.95 (C-H sat.), 1,371.39 \& 1,427.32 ( $\left.\mathrm{CH}_{3}\right), 3,047.53(\mathrm{C}-\mathrm{H}$ unsat.), 1,627.92 ( $\mathrm{C}=\mathrm{C}$, olefine), 1,506.41 \& 1,595.13 ( $\mathrm{C}=\mathrm{C}, \mathrm{Ar})$, 993.34 (trans-olefin), 839.03 ( $p$-subst. Ar).

Compound 2b. m.p. of $182^{\circ} \mathrm{C}-184^{\circ} \mathrm{C}$. IR $(\mathrm{KBr}) v, \mathrm{~cm}^{-1}$ : 1,764.87 $(\mathrm{C}=\mathrm{O}$ acetyl), 1,687.71 $(\mathrm{C}=\mathrm{O}$ conjugated $), 2,823.79 \&$ 2,987.74 (C-H sat.), 1,373.32 \& 1,431.18 ( $\left.\mathrm{CH}_{3}\right), 3,055.24(\mathrm{C}-\mathrm{H}$ unsat.), 1,629.85 $(\mathrm{C}=\mathrm{C}$, olefine $), 1,502.55(\mathrm{C}=\mathrm{C}, \mathrm{Ar}), 985.62$ (trans-olefin), $910.40 \& 829.39$ (C-H tri-substituted aromatic).

\section{Synthesis of Coumaramide $4 a$ and $5 a$ and Caffeamide $4 b$ and $5 b$}

This synthesis was initiated with the chlorination of the compounds $\mathbf{2 a}$ and $\mathbf{2} \mathbf{b}$ using thionyl chloride to produce compounds $\mathbf{3} \mathbf{a}$ and $\mathbf{3} \mathbf{b}$, followed by an in situ amidation reaction using an appropriate amine to produce compounds $\mathbf{4 a}$ and $\mathbf{4 b}$ (from morpholine) as well as $\mathbf{5 a}$ and $\mathbf{5 b}$ (from pyrrolidine). After recrystallization, the pure crystals were obtained as white crystals.

Compound 4a. m.p of $144^{\circ} \mathrm{C}-146^{\circ} \mathrm{C}$. IR (KBr) $v, \mathrm{~cm}^{-1}$ : 3,047.53 (C-H unsat.), 2,829.57 \& 2,981.95 (C-H sat.), 1,747.51 $(\mathrm{C}=\mathrm{O})$ acetyl), 1,683.86 $(\mathrm{C}=\mathrm{O}$ amide $), 1,627.92(\mathrm{C}=\mathrm{C}$ olefin $)$, $1,508.41 \& 1,600.92(\mathrm{C}=\mathrm{C}, \mathrm{Ar}), 1,371.39 \& 1,427.32\left(\mathrm{CH}_{3}\right)$, 1,323.17 (C-N), 993.34 (trans-olefin), 838.03 ( $p$-subst. Ar).

Compound 4b. m.p. of $149^{\circ} \mathrm{C}-151^{\circ} \mathrm{C}$, IR (KBr) $v$, $\mathrm{cm}^{-1}: 3,001.24 \& 3,068.75$ (C-H unsat.), 2,968.45, 2,924.09 \& 2,852.72.07 (sat. $\mathrm{C}-\mathrm{H}), 1,757.15(\mathrm{C}=\mathrm{O}$ acetyl), 1,651.07 $(\mathrm{C}=\mathrm{O}$ amide), 1,610.56 $(\mathrm{C}=\mathrm{C}$, olefin $), 1,502.55 \& 1,610.56(\mathrm{C}=\mathrm{C}, \mathrm{Ar})$, 1,435.04 (C-N amide), 1,377.17 ( $\left.\mathrm{CH}_{3}\right), 1,111.0$ (C-O ether), 972.12 (trans-olefin), $906.54 \& 831.32$ (trisubst. Ar).

Compound 5a. m.p. of $105^{\circ} \mathrm{C}-107^{\circ} \mathrm{C}$. IR $(\mathrm{KBr}) v, \mathrm{~cm}^{-1}$ : 1,761.01 $(\mathrm{C}=\mathrm{O}$, acetyl), 1,683.86 $(\mathrm{C}=\mathrm{O}$, amide), 2,870.08 \& 2,972.31 (C-H sat.), 1,369.76 \& 1,444.68 $\left(\mathrm{CH}_{3}\right), 3,043.67(\mathrm{C}-\mathrm{H}$ unsat.), 1,651.07 ( $\mathrm{C}=\mathrm{C}$, olefin), 1,510.26 \& 1,595.13 ( $\mathrm{C}=\mathrm{C}, \mathrm{Ar})$, 993.34 (trans-olefin), 840.96 ( $p$-subst. Ar), 1,309.67 (C-N).

Compound 5b, m.p. of $156^{\circ} \mathrm{C}-158^{\circ} \mathrm{C}$. IR $(\mathrm{KBr}) v, \mathrm{~cm}^{-1}$ : 1,261.45 (C-N, amide), 1,651.07 ( $\mathrm{C}=\mathrm{O}$, amide), 1,768.72 $(\mathrm{C}=\mathrm{O}$, acetyl ester), 1,109.07 \& 1,193.94 (C-O, acetyl ester), 2,966.52 \& 2,875.85 (C-H, sat.), 1,369.46 (-CH3), 1,435.04 (-CH2, pyrrolidine heterocyclic ring), 3,034.67 (C-H, unsat.), 1,506.41 $\mathrm{cm}^{-1}(\mathrm{C}=\mathrm{C}$ Ar $)$.

\section{Synthesis of $N-(p$-Coumaroyl)amide (6a and 7a) and $N$-(p-Caffeoyl)amide ( $6 \boldsymbol{b}$ and $7 \boldsymbol{b})$}

In this reaction step, recrystallization using ethyl acetate-hexane produced a crystalline form for compounds $\mathbf{6 a}$, $\mathbf{6 b}, \mathbf{7 a}$, and $\mathbf{7 b}$.

Compound 6a. m.p. of $217^{\circ} \mathrm{C}-219^{\circ} \mathrm{C}$. IR $(\mathrm{KBr}) v, \mathrm{~cm}^{-1}$ : 3,219.19 (OH Ar), 3,008.96 (C-H unsat.), 2,860.43, 2,926.01, \& 2,960.73 (C-H sat.), 1,643.35 ( $\mathrm{C}=\mathrm{O}$ amide), 1,606.70 ( $\mathrm{C}=\mathrm{C}$ olefin $)$, 1,514.12 \& 1,585.49 (C=C Ar), 1,440.83 $\left(\mathrm{CH}_{2}\right), 985.82$ (transolefin), 833.25 ( $p$-subst.). ${ }^{1} \mathrm{H}-\mathrm{NMR}(500 \mathrm{MHz}$, chloroform- $d$ ) d, ppm: 3.50-3.80 (8H, overlapped signal $\left(\mathrm{H}^{-} \mathbf{1}^{\prime}+\mathrm{H}-4^{\prime}\right)-\left(\mathrm{H}-2^{\prime}+\mathrm{H}-3^{\prime}\right)$, $5.95(1 \mathrm{H}, s, \mathrm{OH}), 6.70\left(1 \mathrm{H}, d, J_{2,3}=15.4 \mathrm{~Hz}, \mathrm{H}-2\right), 6.85(2 \mathrm{H}, d$, $\left.J_{(6+5),(8+9)}=8.2 \mathrm{~Hz}, \mathrm{H}-6+\mathrm{H}-8\right), 7.41\left(2 \mathrm{H}, d, J_{(5+9),(6+8)}=8.2 \mathrm{~Hz}\right.$, $\mathrm{H}-5+\mathrm{H}-9), 7.6\left(1 \mathrm{H}, d, J_{3,2}=15.4 \mathrm{~Hz}, \mathrm{H}-3\right) .{ }^{13} \mathrm{C}-\mathrm{NMR}(100 \mathrm{MHz}$, acetone- $\left.d_{6}\right)$ d, ppm: $46.46\left(\mathrm{C}-1^{\prime}+\mathrm{C}-4^{\prime}\right), 67.49\left(\mathrm{C}-2^{\prime}+\mathrm{C}-3^{\prime}\right), 115.13$ 
(C-2), 116.49 (C-6+C-8), 128.06 (C-5+C-9), 130.48 (C-4), 142.96 (C-3), 159.84 (C-7), 166.00 (C-1).

Compound 6b. m.p. of $222^{\circ} \mathrm{C}-224^{\circ} \mathrm{C}$. IR (KBr) $v$, $\mathrm{cm}^{-1}$ : 3,421.72 (O-H Ar), 2,854.65 (sat. C-H), 1,641.42 (C=O amide), 1,604.77 \& 1,571.99 ( $\mathrm{C}=\mathrm{C}$ Ar), 1,436.97 (C-N amide), 1,111.0 (C-O ether), 970.19 (trans-olefin), $973.75 \& 808.17$ (trisubst. Ar). ${ }^{1} \mathrm{H}-\mathrm{NMR}(500 \mathrm{MHz}$, chloroform- $d$ ) d, ppm: 3.71 $\left(s, 8 \mathrm{H}, \mathrm{H}-1^{\prime}+\mathrm{H}-2^{\prime}\right), 6.78(d, 1 \mathrm{H}, J=8.05, \mathrm{H}-4), 6.87(d, 1 \mathrm{H}, J=$ 15.35, H-1), 6.99 ( $d, 1 \mathrm{H}, J=8.75, \mathrm{H}-3), 7.05$ ( $s, 1 \mathrm{H}, \mathrm{H}-5), 7.50$ $(d, 1 \mathrm{H}, J=17.95, \mathrm{H}-2), 7.90(s, 1 \mathrm{H},-\mathrm{OH}) .{ }^{13} \mathrm{C}-\mathrm{NMR}(100 \mathrm{MHz}$, chloroform-d d/ppm): 66.45 (C-2'), 112.72 (C-9), 113.99 (C-6), 115.04 (C-2), 120.89 (C-5), 127.06 (C-4), 143.79 (C-3), 145.28 (C-7), 147.56 (C-8), and 166.99 (C-1).

Compound 7a. m.p. of $227^{\circ} \mathrm{C}-229^{\circ} \mathrm{C}$. IR $(\mathrm{KBr}) v, \mathrm{~cm}^{-1}$ : 3,101.54 (OH Ar), 3,064.89 \& 3,003.17 (C-H unsat.), 2,968.45 \& 2,877.79 (C-H sat.), 1,647.21 ( $\mathrm{C}=\mathrm{O}$ amide), 1,570.06 ( $\mathrm{C}=\mathrm{C}$ olefin), 1,510.26 ( $\mathrm{C}=\mathrm{C}$ Ar), 1,446.61 $\left(\mathrm{CH}_{2}\right), 970.19$ (transolefin), 827.46 (p-subst.). ${ }^{1} \mathrm{H}-\mathrm{NMR}\left(500 \mathrm{MHz}\right.$, methanol- $\left.d_{4}\right) \mathrm{d}$, ppm: $1.92\left(2 \mathrm{H}, m, J_{2^{\prime} 3^{\prime}, 1^{\prime}}=6.8 \mathrm{~Hz}, \mathrm{H}-2^{\prime}\right), 2.02\left(2 \mathrm{H}, m, J_{3^{\prime} 2^{\prime}, 4^{\prime}}=6.7\right.$ $\left.\mathrm{Hz}, \mathrm{H}-3^{\prime}\right), 3.52\left(2 \mathrm{H}, t, J_{1^{\prime}, 2^{\prime}}=6.7 \mathrm{~Hz}, \mathrm{H}-1^{\prime}\right), 3.68\left(2 \mathrm{H}, t, J_{4^{\prime}, 3^{\prime}}=6.8\right.$ $\left.\mathrm{Hz}, \mathrm{H}-4^{\prime}\right), 4.88(1 \mathrm{H}, s, \mathrm{OH}), 6.73\left(1 \mathrm{H}, d, J_{23}=15.6 \mathrm{~Hz}, \mathrm{H}-2\right)$, $6.80\left(2 \mathrm{H}, d, J_{(6+8),(5+9)}=7.4 \mathrm{~Hz}, \mathrm{H}-6+\mathrm{H}-8\right), 7.47\left(2 \mathrm{H}, d, J_{(5+9),(6+8)}\right.$ $=7.4 \mathrm{~Hz}, \mathrm{H}-5+\mathrm{H}-9), 7.52(1 \mathrm{H}, d, J=15.4 \mathrm{~Hz}, \mathrm{H}-3) .{ }^{13} \mathrm{C}-\mathrm{NMR}$ (100 MHz, methanol- $\left.d_{4}\right)$ d, ppm: $25.30\left(\mathrm{C}-3^{\prime}\right), 26.99\left(\mathrm{C}-2^{\prime}\right)$, $47.26\left(\mathrm{C}-1^{\prime}\right), 49.92\left(\mathrm{C}-4^{\prime}\right), 116.13(\mathrm{C}-2), 116.72(\mathrm{C}-6+\mathrm{C}-8)$, 127.84 (C-4), 130.90 (C-5+C-9), 143.52 (C-3), 160.74 (C-7), $167.60(\mathrm{C}-1)$.

Compound 7b. m.p. of $204^{\circ} \mathrm{C}-206^{\circ} \mathrm{C}$. IR $\left(\mathrm{KBr}, \mathrm{cm}^{-1}\right)$ : 3,134.67-3,442.94 (OH Ar), 3,043.56 (C-H, unsat.), 2,994.09 (C$\mathrm{H}$, sat.), 1,643.35 ( $\mathrm{C}=\mathrm{O}$, amide), 1,560.41 \& 1,535.34 ( $\mathrm{C}=\mathrm{C}, \mathrm{Ar})$, 1,446.61 ( $-\mathrm{CH}_{2}$, pyrrolidine heterocyclic ring), $1,273.02(\mathrm{C}-\mathrm{N}$, amide). ${ }^{1} \mathrm{H}-\mathrm{NMR}\left(500 \mathrm{MHz}\right.$, methanol- $\left.d_{4}\right) \mathrm{d}$, ppm: $1.93 \mathrm{ppm}(2 \mathrm{H}$, $\left.m, J=27.2 \mathrm{~Hz}, \mathrm{H}-3^{\prime}\right), 2.03 \mathrm{ppm}\left(2 \mathrm{H}, m, J=27.65 \mathrm{~Hz}, \mathrm{H}-2^{\prime}\right), 3.53$ ppm $\left(2 \mathrm{H}, t, J=13.6 \mathrm{~Hz}, \mathrm{H}-4^{\prime}\right), 3.69 \mathrm{ppm}(2 \mathrm{H}, t, J=13.55 \mathrm{~Hz}$, H-1'), $6.67(1 \mathrm{H}, d, J=15.45 \mathrm{~Hz}, \mathrm{H}-2), 6.78(1 \mathrm{H}, d, J=8.15 \mathrm{~Hz}$, $\mathrm{H}-8), 6.97(1 \mathrm{H}, d, J=8.15 \mathrm{~Hz}, \mathrm{H}-9), 7.05(1 \mathrm{H}, s, \mathrm{H}-5), 7.46(1 \mathrm{H}$, $d, J=15.4 \mathrm{~Hz}, \mathrm{H}-3) .{ }^{13} \mathrm{C}-\mathrm{NMR}\left(100 \mathrm{MHz}\right.$, methanol- $\left.d_{4}\right) \mathrm{d}$, ppm: $23.87\left(\mathrm{C}-3^{\prime}\right), 25.57\left(\mathrm{C}-2^{\prime}\right), 45.83\left(\mathrm{C}-4^{\prime}\right), 46.48\left(\mathrm{C}-1^{\prime}\right), 113.88(\mathrm{C}-$ 5), 114.68 (C-8), 115.05 (C-2), 120.94 (C-9), 127.02 (C-4), 142.49 (C-3), 145.30 (C-6), 147.55 (C-7), 166.20 (C-1).

\section{Docking study}

\section{Preparation of protein receptor and ligand standard}

The crystal structure of the protein receptor human DNA topoisomerase (Top1) was downloaded from the Protein Data Bank webpage (https:/www.rcsb.org/structure/1T8I). All of the residues were removed and selected under the docking preparation menu in Chimera software (Pettersen et al., 2004). Camptothecin $(\mathrm{Cpt})$ as a standard ligand was extracted from the protein complexes file and saved in a .pdb file format.

\section{Preparation of ligand}

A set of novel hydroxycinnamamides was constructed using Avogadro software (Hanwell et al., 2012). Then, all ligands were prepared to dock by optimizing the structure in Chimera software using the AM1-BCC semiempirical method and saved in a .pdb file format.

\section{Molecular docking}

The docking process was done using AutoDock 4.2 software with the help of AutoDockTools program (Morris and Huey, 2009). Each ligand was docked into the active site of Top1 protein receptor. Grid box size was set at $40 \times 40 \times 40 \AA$ with spacing $0.375 \AA$ and saved as parameter file in .gpf format file. The docking procedure was set to produce 10 conformations and run for a maximum energy evaluation of 2,500,000. The Lamarckian genetic algorithm was used to obtain data in the form of binding energy $(\mathrm{kcal} / \mathrm{mol})$ and predicted inhibition constant. Validation of docking was determined from the value of root mean square deviation (RMSD) of the redocking standard ligand into the active site of the protein receptor. The successful the redocking process was known from a low RMSD value of about less than $2 \AA$ (Huey et al., 2007). Visualization of docking results was exhibited by using Discovery Studio Visualizer software for windows (Dassault Systemes, 2019).

\section{Activity study against P388 leukemia murine cells}

The activity assay procedure against P388 leukemia murine cells of compounds $\mathbf{6 a}, \mathbf{6 b}, \mathbf{7 a}$, and $7 \mathbf{b}$ was conducted according to a previous method (Kuncoro et al., 2003) in a single performed test.

\section{RESULTS AND DISCUSSION}

\section{Synthesis and characterization}

Theoretically, a proper synthetic method of amide can be undertaken from carboxylic acid with an amine, through the amidation reaction using a boric acid catalyst (Tang et al., 2012). However, that reaction did not succeed in the conversion of the hydroxycinnamic acid to its amide. This is presumably alleged due to the presence of the phenolic group in the benzene ring, which has an acidic property, so that it may turn into unexpected products. Therefore, it is necessary to protect the hydroxyl group, usually using an acetyl group ( $\mathrm{Lu}$ and Ralph, 1998). Without a protective group in the phenolic hydroxyl group, a polymerization reaction will occur when the carboxylic group has been converted to its halide.

In this study, the hydroxyl groups of $p$-coumaric (1a) and $p$-caffeic acid (1b) were protected with acetyl using acetic anhydride (Figure 1). The products from each reaction step were analyzed with an FTIR spectrometer for identification purpose, except for the chlorination products. Specifically, for the deacetylation products, the FTIR analysis was continued with ${ }^{1} \mathrm{H}-\mathrm{NMR}$ and ${ }^{13} \mathrm{C}$-NMR spectrometers, as well as heteronuclear single quantum coherence and heteronuclear multiple bond correlation (HMBC).

In the acetylation stage, besides the loss of the absorption band of O-H phenolic groups in the range of 3,200-3,300 $\mathrm{cm}^{-1}$ on the IR spectra of acetylation products (compounds $\mathbf{2 a - b}$ ), the spectra also have no longer showed the absorption band of the carboxylic O-H group in the area of 2,500-3,200 $\mathrm{cm}^{-1}$. Both facts indicated that acetylation had occurred in the phenolic groups, while the carboxylic acid groups turned into acetic anhydride. However, in the chlorination with thionyl chloride, only the carboxylic anhydrate groups were chlorinated, while the phenolic ester groups did not experience chlorination. Thus, it can be stated that thionyl chloride was selective in chlorinating. The 


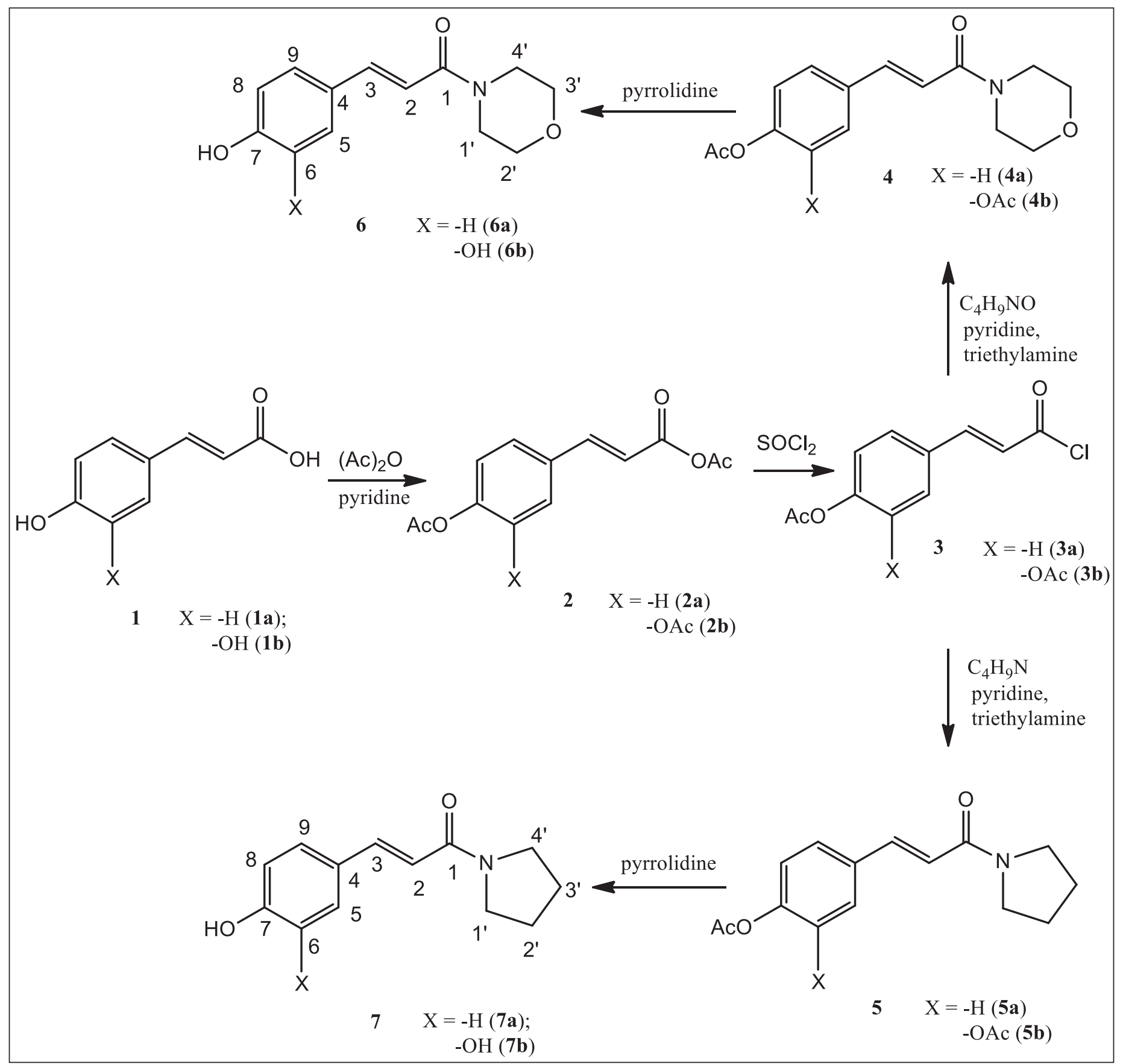

Figure 1. Synthesis pathway.

selectivity of these chlorinating agents has also been confirmed by Greenberg and Sammakia (2017), which reported that benzyl ester is unreactive to thionyl chloride. Thus, it cannot be converted into acid chloride.

The successful conversions of compounds $\mathbf{3} \mathbf{a}-\mathbf{b}$ to compounds $\mathbf{4} \mathbf{a}-\mathbf{b}$ and $\mathbf{5} \mathbf{a}-\mathbf{b}$ were indicated by the existence of an IR absorption band of C-N at about $3,100 \mathrm{~cm}^{-1}$ for secondary amide. In the IR spectra of all compounds, the absorption band of acetyl $\mathrm{C}=\mathrm{O}$ was around $1,770-1,740 \mathrm{~cm}^{-1}$. The loss of the carboxylate ester band and the emergence of the hydroxyl absorption band of the phenolic group around 3,200-3,400 $\mathrm{cm}^{-1}$ were used as an indication of successful deacetylation, which produced compounds $\mathbf{6 a}-\mathbf{b}$ and $7 \mathbf{a}-\mathbf{b}$.

The ${ }^{13} \mathrm{C}$-NMR spectra of all compounds also provided signals that corresponded to the structures of $\mathbf{6 a -}-\mathbf{b}$ and $7 \mathbf{a}-\mathbf{b}$. The ${ }^{13} \mathrm{C}$-NMR spectra of compound $\mathbf{6} \mathbf{a}-\mathbf{b}$ conveyed nine signals representing 13 carbon atoms. In this case, there were four equivalent pairs of carbon atoms, namely, C-5 and C-9, C-6 and C-8, C-1' and C-4', and C-2' and C-3'. However, the ${ }^{13} \mathrm{C}-\mathrm{NMR}$ spectra of compounds $\mathbf{7 a - b}$ showed 11 signals, more than the 
signal displayed by compounds $\mathbf{6 a}-\mathbf{b}$, due to the absence of equivalent carbon in the five-membered amino ring moieties. The different environments of four carbons in pyrrolidine moiety are presumably due to the nonplanar geometry, which is expected to have an envelope conformation. This conformation cannot be inverted at room temperature due to its high inversion energy (ElGogary and Soliman, 2001).

In the ${ }^{1} \mathrm{H}-\mathrm{NMR}$ spectra, all compounds were also distinguished by the signals that emerged from their amino group protons. Each of the compounds $\mathbf{6 a}$ and $\mathbf{6 b}$ gave two doublet signals with the coupling constant from the group which were 15.4 and $15.35 \mathrm{~Hz}$, respectively. On the other hand, each of the compounds $7 \mathbf{a}$ and $\mathbf{7 b}$ showed two triplet signals and two multiplet signals with coupling constants of 6.7-6.8 $\mathrm{Hz}$ and $13.55-27.65 \mathrm{~Hz}$, respectively. The other signals from all compounds have the same profile and shift value, which are also almost similar to the signals coming from equivalent carbon atoms.

The structure of compound 7a has also been confirmed by the HSQC and HMBC methods. Both spectra are shown in Figures 2 and 3.
Based on the HSQC spectra, the correlation of one bond between a hydrogen atom and a carbon atom in the structure of compound 7a is shown in Figure 4. Also, the multibond correlation between a hydrogen atom and carbon atoms, according to the HMBC spectra, is shown in Figure 5. Figure 4 shows that all hydrogen atoms are positively correlated to the carbon atoms in which they are bonded. Furthermore, Figure 5 shows two types of correlations between hydrogen atoms and carbon atoms with two spaced bonds as a short distance correlation (blue curved arrows) and long-distance correlations, three and four bonds (red curved arrows). Figure 5 also shows a positive correlation between the hydrogen atoms and the carbon atoms of the pyrrolidinyl group. In addition to the correlation between the two bonds, the atoms also show the correlation between the three bonds.

Similarly, the attachment of the olefin group to the carbonyl group is shown by the correlation of olefin hydrogen atoms in two bonds and the correlation in three bonds. Furthermore, the attachment of the olefin group to the aromatic group is shown by the correlation of the $\mathrm{H}-2$ olefin group to the $\mathrm{C}-4$ aromatic group.

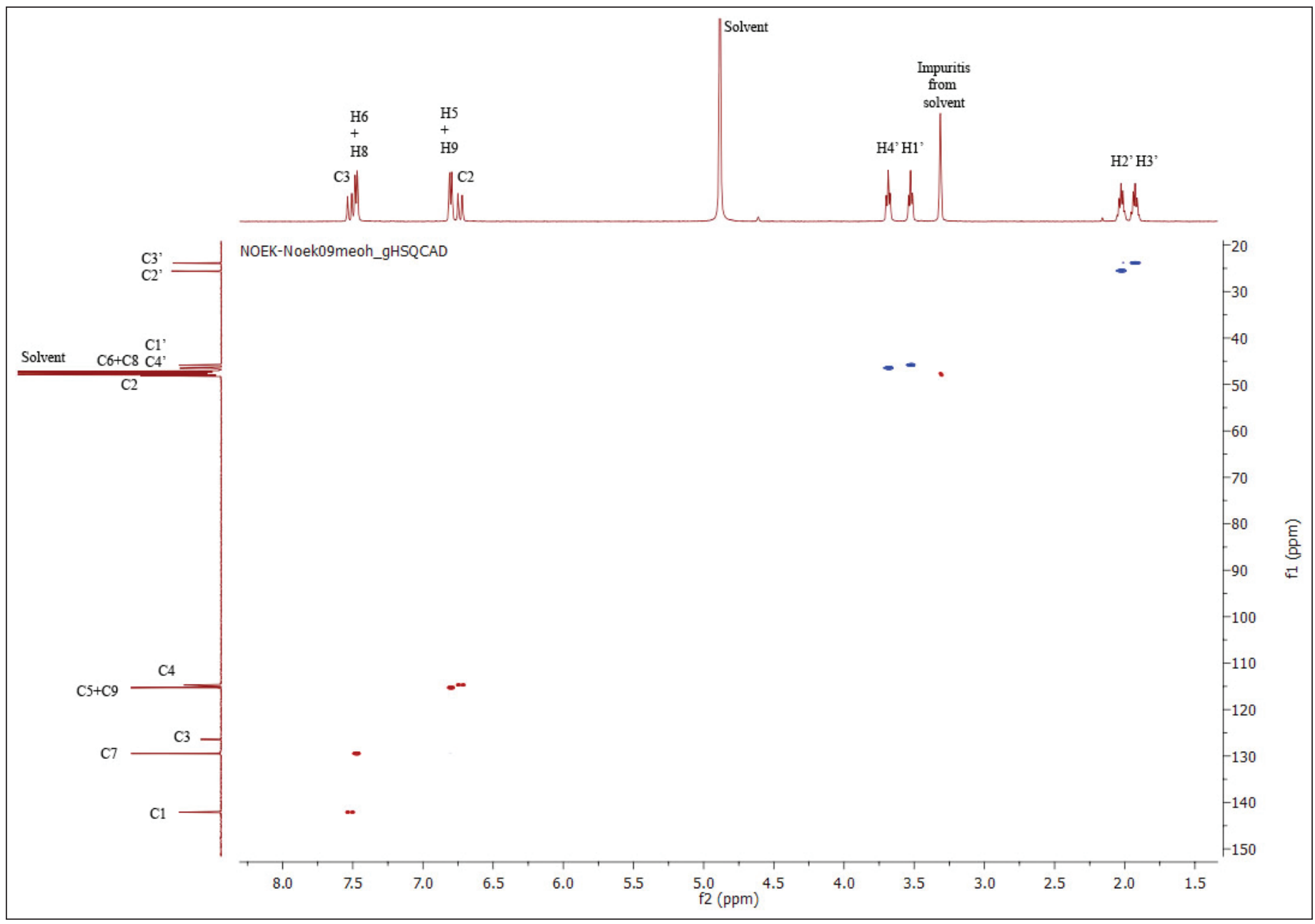

Figure 2. HSQC spectra of compound 7a. 


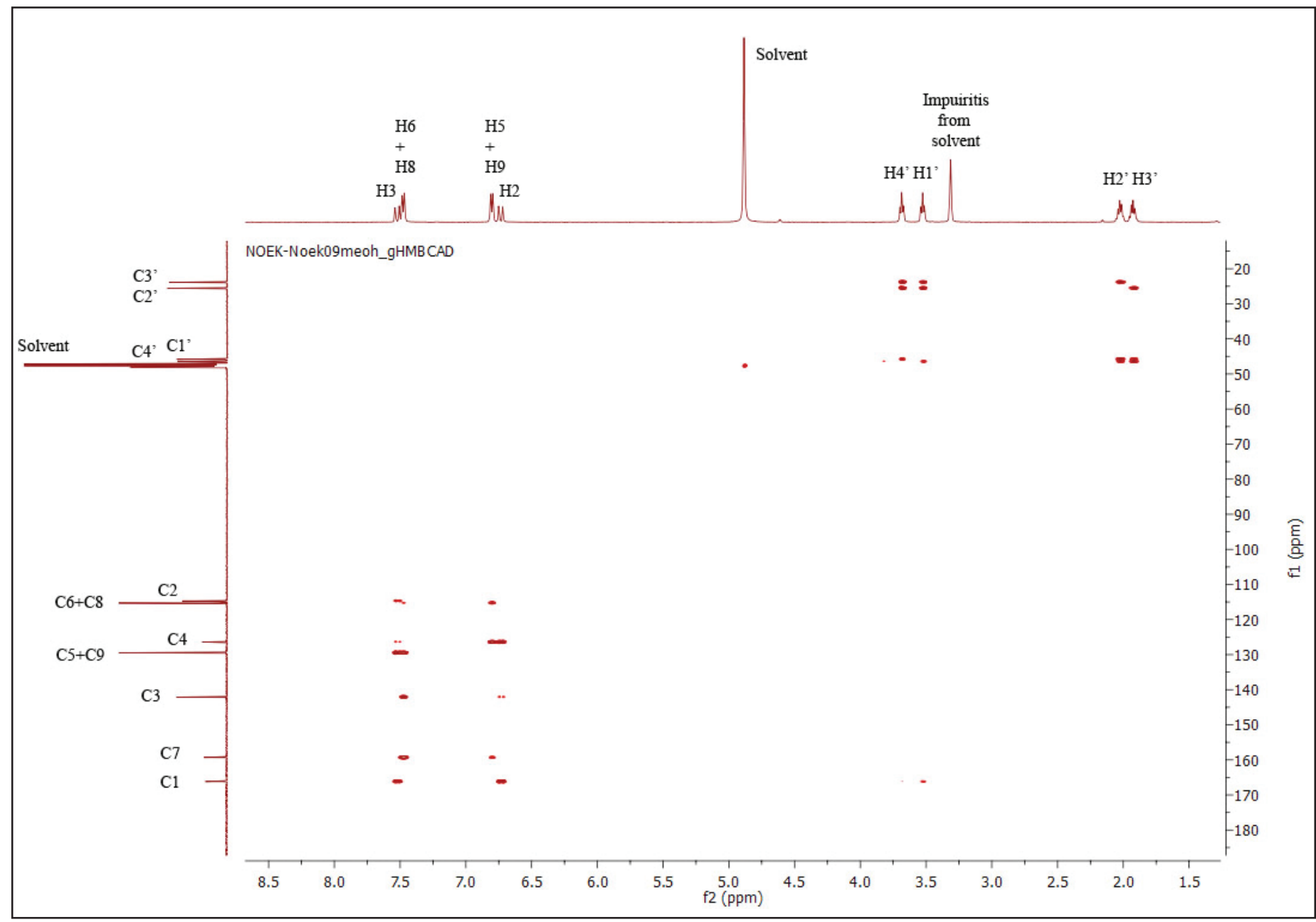

Figure 3. HMBC spectra of compound 7a.

Table 1. Molecular docking results of the new compound against Top1 protein.

\begin{tabular}{cccc}
\hline Compound & $\boldsymbol{\Delta G} \mathbf{( k c a l} / \mathbf{m o l})$ & $\mathbf{K i}(\boldsymbol{\mu M})$ & Hydrogen bond interaction \\
\hline $\mathbf{6 a}$ & -5.42 & 106.65 & Thr718 \\
& & & Thr718 \\
$\mathbf{6 b}$ & -5.58 & 80.91 & Asn722 \\
& & & Asn722 \\
$7 \mathbf{7 a}$ & -5.40 & 110.23 & Thr718 \\
& & & Asn722 \\
$7 \mathbf{7 b}$ & -5.55 & 85.28 & Asn722 \\
& & & DC D:112 \\
\hline
\end{tabular}

Table 2. The anticancer activity values of synthesized compounds.

\begin{tabular}{cc}
\hline Compound & $\mathbf{I C}_{50}(\mu \mathrm{g} / \mathrm{ml})$ \\
\hline $\mathbf{6 a}$ & 19.35 \\
$\mathbf{6 b}$ & 1.48 \\
$\mathbf{7 a}$ & 53.46 \\
$\mathbf{7 b}$ & 11.35 \\
\hline
\end{tabular}

\section{Docking study}

A molecular docking study has been conducted between $\mathbf{6 a}, \mathbf{6 b}, \mathbf{7} \mathbf{a}$, and $\mathbf{7 b}$ against the human topoisomerase I (Top1) receptor. This protein receptor is the molecular target of a diverse set of anticancer compounds (Laco et al., 2002; Ismail et al., 2010). Table 1 shows the result of molecular docking of all compounds against the Top1 receptor. As can be seen from Table 1, compound $\mathbf{6 b}$ performed the lowest binding energy than the other compounds due to the presence of hydrogen bonds and other intermolecular interactions. Figure 6 shows a 2D intermolecular interaction of compound $\mathbf{6} \mathbf{b}$ with the Top 1 receptor. There were three hydrogen bonds, two pi-pi stacking, and pi-alkyl stacking interactions.

\section{Activity against P388 leukemia murine cells}

The activity assay of all compounds is shown in Table 2. Based on the $\mathrm{IC}_{50}$ values, compounds $\mathbf{6 a}, \mathbf{6 b}$, and $7 \mathbf{b}$ exhibited intense anticancer activity against P388 leukemia murine cells, especially for compound $\mathbf{6 b}$, which performed $\mathrm{IC}_{50}$ below $10 \mu \mathrm{g} / \mathrm{ml}$. Caffeamide of both morpholine and 


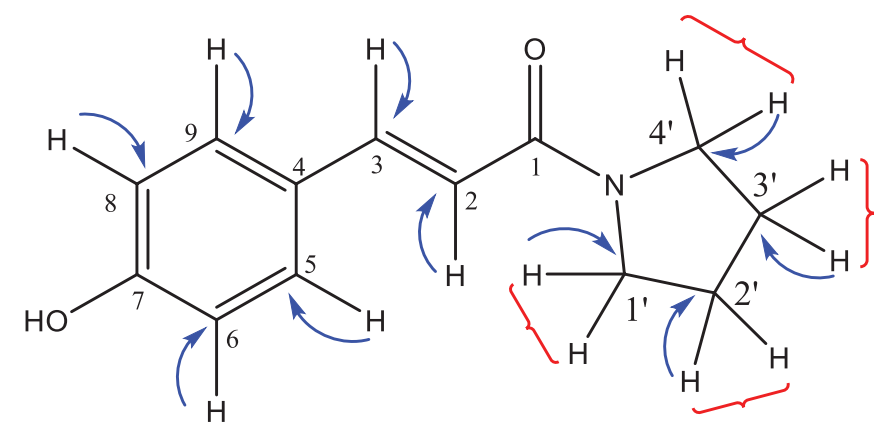

Figure 4. One bond correlation of hydrogen and carbon atoms in the structure compound $7 \mathbf{a}$.

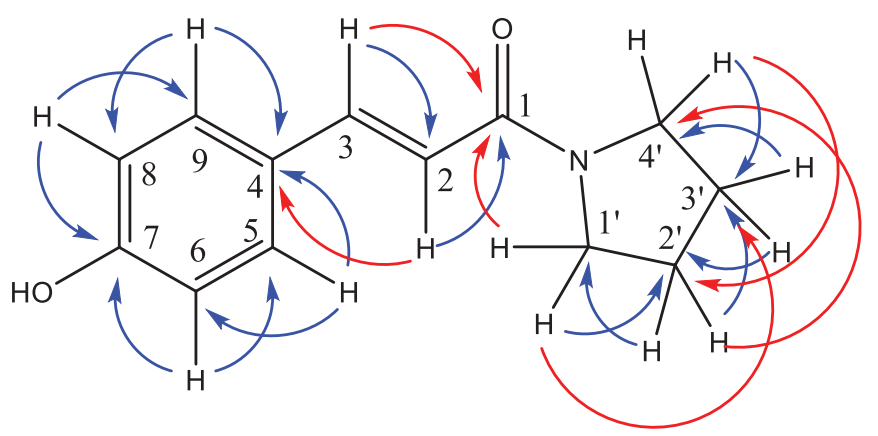

Figure 5. HMBC spectra of compound 7a. Blue arrow: two bond correlation; and red arrow: three bond correlation.

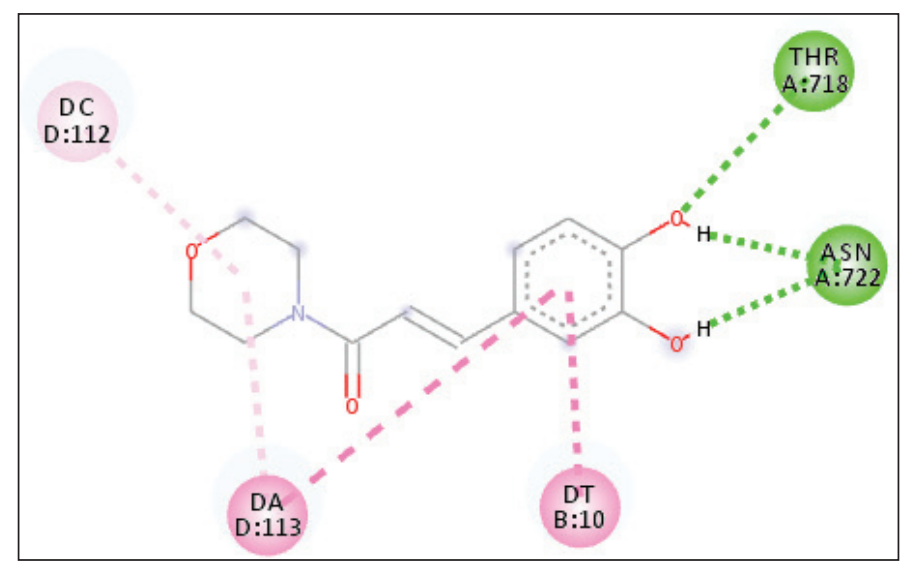

Figure 6. 2D interaction of ligand $\mathbf{6 b}$ against Top 1 protein receptor (hydrogen bond, pi-pi stacking, and pi-alkyl stacking).

pyrrolidine showed more vigorous anticancer activity than the analog coumaramides. Compared to $\mathbf{6 a}$, which has a difference only in the presence of the hydroxyl group on $\mathrm{C}-6$, the activity of $\mathbf{6 b}$ was superior. It showed that this $-\mathrm{OH}$ group has an essential role in its activity against P388 murine leukemia cells. As shown in the docking study, it is due to the presence of an intramolecular hydrogen bond between the adjacent hydroxyl groups, which can stabilize the structure after releasing hydrogen radicals. This result is consistent with the previous report related to the comparison of anticancer activity between caffeamide and $p$-coumaramide (Firdaus et al., 2019).

Meanwhile, compared to the activity of $p$-coumaramide that was isolated from Kleinhovia Hospita L. $\left(\mathrm{IC}_{50}\right.$ of $44.00 \mu \mathrm{g} / \mathrm{ml}$ ) (Firdaus et al., 2014) and $N$-feruloyl morpholine which previously synthesized ( $\mathrm{IC}_{50}$ of 46.67) (Firdaus et al., 2017), compound 6a was considerably more active. The different activities of $\mathbf{6 a}$ compared to $p$-coumaramide may be due to the difference in the polarity of the two compounds. The polarity of $6 \mathrm{a}$ with amine morpholine moiety is lower than the $p$-coumaramide compound, which is a primary amide. Therefore, it is easier for $6 a$ to penetrate the lipophilic cell shield. However, this concept cannot be used to explain the differences in the activity of compounds 6a and $\mathrm{N}$-feruloyl morpholine. Structurally, 6a and N-feruloyl morpholine have a difference only in the phenolic groups. The $\mathrm{N}$-feruloyl morpholine contains a methoxy group at the ortho position to a hydroxyl group, where both groups are ready to form an intramolecular hydrogen bonding. This bond decreases the polarity of the compound so that its ability to penetrate cell shields increases, and it is expected to increase its activity. However, this is contrary to the fact.

To explain the difference in activity between compound 6a and $N$-feruloyl morpholine, we must review other factors that have a perspective of influencing a compound"s ability to transfer hydrogen radicals (Hatfield et al., 2008; Zhang et al., 2015). The p-hydroxycinnamic compounds are ready to transfer hydrogen radicals because the release of hydrogen radicals will leave relatively stable radicals due to the delocalization of the unpaired electrons to carbonyl groups (Georgiev et al., 2012). Therefore, the hydrogen bond at $\mathrm{N}$-feruloyl morpholine obstructs the release of hydrogen radicals, and this effect is reflected in the low activity of this compound rather than compound $\mathbf{6 a}$.

\section{CONCLUSION}

Four amide compounds have been synthesized from p-coumaric and caffeic acid via acetylation, chlorination, amidation, and deacetylation, sequentially. Docking study showed that compound $\mathbf{6 b}$ had the lowest binding energy value and had some intermolecular interaction against Top1 receptor. All compounds were active against P388 murine leukemia cells with the $\mathrm{IC}_{50}$ of $19.35,1.48,53.46$, and $11.35 \mu \mathrm{g} / \mathrm{ml}$ for compounds $\mathbf{6 a}$, $\mathbf{6 b}, 7 \mathbf{a}$, and $7 \mathbf{b}$, respectively.

\section{ACKNOWLEDGMENTS}

The authors acknowledge the Chemistry Laboratory and Natural Products Laboratory of Mathematics and Science Faculty, Institute Technology of Bandung, for access to the NMR measurements and the testing facilities in performing the antitumor activity of these compounds. They also acknowledge the Integrated Chemistry Laboratory of Chemistry Department, Mathematics and Science Faculty, Hasanuddin University, for FTIR measurements. 


\section{AUTHOR CONTRIBUTIONS}

All authors made substantial contributions to conception and design, acquisition of data, or analysis and interpretation of data; took part in drafting the article or revising it critically for important intellectual content; agreed to submit to the current journal; gave final approval of the version to be published; and agree to be accountable for all aspects of the work.

\section{FUNDING}

There is no funding to report.

\section{CONFLICTS OF INTEREST}

The authors report no conflicts of interest in this work.

\section{ETHICAL APPROVAL}

This study does not involve the use of animals or human subjects.

\section{REFERENCES}

Boudreau LH, Maillet J, LeBlanc LM, Jean-François $\mathrm{J}$ Touaibia M, Flamand N, Surette ME. Caffeic acid phenethyl ester and its amide analogue are potent inhibitors of leukotriene biosynthesis in human polymorphonuclear leukocytes. PLoS One, 2012; 7(2):e31833; doi: 10.1371/journal.pone.0031833

Bray F, Ferlay J, Soerjomataram I, Siegel RL, Torre LA, Jemal A. Global cancer statistics 2018: globocan estimates of incidence and mortality worldwide for 36 cancers in 185 countries. CA Cancer J Clin, 2018; 68(6):394-424; doi: 10.3322/caac.21492

Chorawala M, Oza P, Shah G. Mechanisms of anticancer drugs resistance: an overview. Int J Pharm Sci Drug Res, 2012; 4(1):1-9.

Dassault Systemes. Biovia discovery studio visualizer. Dassault Systemes, San Diego, CA, 2019.

Dillekås H, Rogers MS, Straume O. Are $90 \%$ of deaths from cancer caused by metastases? Cancer Med, 2019; 8(12):5574-6; doi: $10.1002 / \mathrm{cam} 4.2474$

Dutta S, Ray S, Nagarajan K. Glutamic acid as anticancer agent: an overview. Saudi Pharm J, 2013; 21(4):337-43; doi: 10.1016/j. jsps.2012.12.007

Ekowati J, Tejo BA, Sasaki S, Highasiyama K, Sukardiman, Siswandono, Budiati T. Structure modification of ethyl p-methoxycinnamate and their bioassay as chemopreventive agent against mice 'S Fibrosarcoma. Int J Pharm Pharm Sci, 2012; 4:1-5.

El-Gogary TM, Soliman MS. Ab-Initio molecular geometry and normal coordinate analysis of pyrrolidine molecule. Spectrochim Acta Part A Mol Biomolecular Spectrosc, 2001; 57(13):2647-57.

Firdaus. Methylation of p-coumaric acid with dimethyl sulfate and sodium hydroxide as catalyst. The first International Conference on Science (ICOS)-I 2014, Makassar, Indonesia: IOP, 2014, pp 339-44.

Firdaus. Synthesis of piperidine and morpholine amides of ferulic acid and their bioactivity against P-388 Leukemia Cells. Int J ChemTech Res, 2017; 10(1):27-33.

Firdaus, Seniwati, Alamsyah N, Paramita S. Synthesis and activity of N-(o-tolyl)caffeamide and N-(o-tolyl)-p-coumaramide against P388 leukemia murine cells. J Phys Conf Ser, 2019; 1341:032005.

Georgiev L, Chochkova MG, Ivanova G, Najdenski H, Ninova M, Milkova T. Radical scavenging and antimicrobial activities of cinnamoyl amides of biogenic monoamines. Riv Ital delle Sostanze Grasse, 2012; 89(2):91-102.
Greenberg JA, Sammakia T. The conversion of tert-butyl esters to acid chlorides using thionyl chloride. J Org Chem, 2017; 82(6):3245-51.

Hanwell MD, Curtis DE, Lonie DC, Vandermeersch T, Zurek E, Hutchison GR. Avogadro: an advanced semantic chemical editor, visualization , and analysis platform. J Cheminform, 2012; 4(17):1-17.

Hatfield R, Ralph J, Grabber JH. A potential role for sinapyl p-coumarate as a radical transfer mechanism in grass lignin formation Planta, 2008; 228(6):919-28; doi: 10.1007/s00425-008-0791-4

Huey R, Morris GM, Olson AJ, Goodsell DS. A semiempirical free energy force field with charge-based desolvation. J Comput Chem, 2007; 28(6):1145-52; doi: 10.1002/jcc

Ismail MMF, Rateb HS, Hussein MMM. European journal of medicinal chemistry synthesis and docking studies of novel benzopyran-2ones with anticancer activity. Eur J Med Chem, 2010; 45(9):3950-9; doi: 10.1016/j.ejmech.2010.05.050

Kakde D, Jain D, Shrivastava V, Kakde R, Patil AT, Srivastava V, Patil A, Jain D, Patil AT, Patil A, Kakde R, Patil PA, Patil AG. Cancer therapeutics- opportunities, challenges and advances in drug delivery. $\mathrm{J}$ Appl Pharm Sci, 2011; 1(9):1-10.

Kamble SS, Shegokar HD, Kamble VA. Synthesis of new 4-chloro-(5-aliphatic/cyclic saturated amino)-2-o-chlorophenyl-(2H)pyridazin-3-one derivatives as anticancer, antiangiogenic, and antioxidant agents. J Basic Appl Res Int, 2017; 21(1):10-39.

Karakaya G, Türe A, Ercan A, Öncül S, Aytemir MD. Synthesis, computational molecular docking analysis and effectiveness on tyrosinase inhibition of kojic acid derivatives. Bioorg Chem, 2019; 88:102950; doi: 10.1016/j.bioorg.2019.102950

Kuncoro H, Rijai L, Julaeha E, Supratman U. Cytotoxic activity against P-388 murine leukemia cell from lygodium microphyllum herb. J Farmasi Galenika, 2003; 3(1):13-6.

Kuo YY, Jim WT, Su LC, Chung CJ, Lin CY, Huo C, Tseng JC, Huang SH, Lai CJ, Chen BC, Wang BJ, Chan TM, Lin HP, Chang WSW, Chang CR, Chuu CP. Caffeic acid phenethyl ester is a potential therapeutic agent for oral cancer. Int J Mol Sci, 2015; 16(5):10748-66; doi: 10.3390/ijms160510748

Laco GS, Collins JR, Luke B, Kroth H, Sayer J, Jerina DM, Pommier Y. Articles human topoisomerase I inhibition : docking camptothecin and derivatives into a structure-based active site model $\uparrow$. 2002; 41(5):1428-35.

Liu Z, Fu J, Shan L, Sun Q, Zhang W. Synthesis, preliminary bioevaluation and computational analysis of caffeic acid analogues. Int $\mathrm{J}$ Mol Sci, 2014; 15(5):8808-20; doi: 10.3390/ijms15058808

$\mathrm{Lu} \mathrm{F}$, Ralph J. Facile synthesis of 4-hydroxycinnamyl p -coumarates. J Agric Food Chem, 1998; 46:2911-3.

Lu S, Zheng W, Luo LJQ, Hao X, Li X, Wang Fl. 'Synthesis, characterization, screening and docking analysis of 4-anilinoquinazoline derivatives as tyrosine kinase inhibitors. European J Med Chem, 2013; 61:84-94; doi: 10.1016/j.ejmech.2012.07.036

Łukowska-Chojnacka E，Kowalkowska A， Gizińska M, Koronkiewicz M, Staniszewska M. Synthesis of tetrazole derivatives bearing pyrrolidine scaffold and evaluation of their antifungal activity against Candida albicans. Eur J Med Chem, 2019; 164:106-20; doi: 10.1016/j.ejmech.2018.12.044

Magalhaes LG, Ferreira LLG, Andricopulo AD. Recent advances and perspectives in cancer drug design. An Acad Bras Cienc, 2018; 90(1):1233-50; doi: 10.1590/0001-3765201820170823

Morris G, Huey R. AutoDock4 and AutoDockTools4: automated docking with selective receptor flexibility. J Comput Chem, 2009; 30(16):2785-91; doi: 10.1002/jcc.21256.AutoDock4

Ozturk G, Ginis Z, Akyol S, Erden G, Gurel A, Akyol O. The anticancer mechanism of caffeic acid phenethyl ester (CAPE): review of melanomas, lung and prostate cancers. Eur Rev Med Pharmacol Sci, 2012; 16(15):2064-8 
Peng W, Wu JG, Jiang YB, Liu YJ, Sun T, Wu N, Wu CJ. Antitumor activity of 4-O-(2"-O-acetyl-6"-O-p-coumaroyl- $\beta$-dglucopyranosyl)-p-coumaric acid against lung cancers via mitochondrialmediated apoptosis. Chem Biol Interact, 2015; 233(1166):8-13; doi: 10.1016/j.cbi.2015.03.014

Pettersen EF, Goddard TD, Huang CC, Couch GS, Greenblatt DM, Meng EC, Ferrin TE. UCSF chimera - a visualization system for exploratory research and analysis. J Comput Chem, 2004; 25(13):1605-12.

Qin X, Lv Y, Liu P, Li Z, Hu L, Zeng C, Yang Ll. 'Novel morpholin-3-one fused quinazoline derivatives as EGFR tyrosine kinase inhibitors. Bioorg Med Chem Lett, 2016; 26(6):1571-5; doi: 10.1016/j. bmcl.2016.02.009

Rajan P, Vedernikova I, Cos P, Berghe DV, Augustyns K, Haemers A. Synthesis and evaluation of caffeic acid amides as antioxidants. Bioorg Med Chem Lett, 2001; 11:215-7.

Rocha LD, Monteiro MC, Teodoro AJ. Anticancer properties of hydroxycinnamic acids -a review. Cancer Clin Oncol, 2012; 1(2):109-21; doi: 10.5539/cco.v1n2p109

Said M, Badshah A, Shah NA, Khan H, Murtaza G, Vabre B, Zargarian D, Khan MR. Antitumor, antioxidant and antimicrobial studies of substituted pyridylguanidines. Molecules, 2013; 18(9):10378-96; doi: 10.3390/molecules 180910378

Sarkar S, Horn G, Moulton K, Oza A, Byler S, Kokolus S, Longacre M. Cancer development, progression, and therapy: an epigenetic overview. Int J Mol Sci, 2013; 14(10):21087-113; doi: 10.3390/ ijms141021087

Siegel RL, Miller KD, Jemal A. Cancer statistics, 2019. CA: Cancer J Clin, 2019; 69(1):7-34; doi: 10.3322/caac.21551.

Spencer JPE, Abd El Mohsen MM, Minihane AM, Mathers JC. Biomarkers of the intake of dietary polyphenols: strengths, limitations and application in nutrition research. Br J Nutr, 2008; 99(1):12-22; doi: 10.1017/S0007114507798938

Sudhakar A. History of cancer, ancient and modern treatment methods. J Cancer Sci Ther, 2009; 01(02):i-iv; doi: 10.4172/1948$5956.100000 \mathrm{e} 2$
Surendra Kumar R, Moydeen M, Al-Deyab SS, Manilal A, Idhayadhulla A. Synthesis of new morpholine-connected pyrazolidine derivatives and their antimicrobial, antioxidant, and cytotoxic activities. Bioorganic Med Chem Lett, 2017; 27(1):66-71; doi: 10.1016/j. bmcl.2016.11.032

Tang P, Acid B, Amidation C. Discussion addendum for: boric acid catalyzed amide formation from carboxylic acids and amines: $n$-benzyl-4-phenylbutyramide. Organic Synth, 2012; 89(Figure 1):432; doi 10.15227/orgsyn.089.0432

Teixeira J, Gaspar A, Garrido EM, Garrido J, Borges F. (2013). Hydroxycinnamic acid antioxidants: an electrochemical overview. BioMed Res Int, 2013; 2013:1-11; doi: 10.1155/2013/251754.

Yao N, Liu DL, Li YJ, Chen Z, Shi Z, Chen W, Yao Z, Zhang D, Ye W. B5H7, a morpholine derivative of 23-hydroxybetulinic acid, reverses doxorubicin resistance in HepG2/ADM. J Can Res Updates, 2014;3:59-66; doi: 10.6000/1929-2279.2014.03.01.6.

Zhang B, Lv C, Li W, Cui Z, Chen D, Cao F, Miao F, Zhou L. Ethyl cinnamate derivatives as promising high-efficient acaricides against psoroptes cuniculi: synthesis, bioactivity and structure-activity relationship. Chem Pharm Bull, 2015; 63(4):255-62; doi:10.1248/cpb.c14-00765.

\section{How to cite this article:}

Firdaus, Soekamto NH, Firdausiah S, Rasyid H, Asmi N, Waelulu M. Novel hydroxycinnamamide from morpholine and pyrrolidine: Synthesis, characterization, docking study, and anticancer activity against P388 leukemia murine cells. J Appl Pharm Sci, 2021; 11(01):040-048. 